\title{
Tumor necrosis factor-alpha and the cytokine network in psoriasis
}

Fator de necrose tumoral-alfa e a rede de citocinas na psoriase

\author{
Arles Martins Brotas ${ }^{1}$ \\ Eduardo Henrique Jorge Lago ${ }^{3}$ \\ Sueli Coelho da Silva Carneiro ${ }^{5}$
}

\author{
José Marcos Tellas Cunha ${ }^{2}$ \\ Cristiane Chaves Nascentes Machado ${ }^{4}$
}

\begin{abstract}
New molecular methods of research have greatly expanded the knowledge about the role of cytokines in several diseases, including psoriasis. The work orchestrated by these peptides is essential for the communication between resident inflammatory cells (keratinocytes and endothelial cells) and infiltrating cells (neutrophils, lymphocytes, Langerhans cells). This is a complex network due to redundancy, synergism and, sometimes, the antagonism of cytokines, which prevents full understanding of the pathogenesis of the disease. Currently, it seems premature to try to establish a main actor, but TNFalpha participates in all stages of psoriatic plaque development, as we shall see.
\end{abstract}

Keywords: Cytokines; Psoriasis; Tumor necrosis factor-alpha

Resumo: A introdução de novos métodos moleculares de investigação ampliou muito o conhecimento sobre o papel das citocinas em diversas doenças, entre elas a psoríase. O trabalho orquestrado desses polipeptídeos é fundamental na comunicação entre as células inflamatórias residentes (queratinócitos e células endoteliais) e infiltrantes (neutrófilos, linfócitos, células de Langerhans). Trata-se de uma rede complexa devido à redundância, ao sinergismo e, por vezes, ao antagonismo das citocinas, o que dificulta a compreensão da fisiopatogenia da doença a partir de um mecanismo linear. No momento atual, parece precoce tentar estabelecer um regente, mas o TNF-alfa se destaca em todos os passos do desenvolvimento da placa psoriásica, como veremos a seguir.

Palavras-chave: Citocinas; Fator de necrose tumoral alfa; Psoríase

Received on 30.03.2011.

Approved by the Advisory Board and accepted for publication on 19.07.2011.

Work conducted at the Federal University of Rio de Janeiro (UFRJ) - Rio de Janeiro (RJ), Brazil

Conflict of interest: None

Financial funding: None

PhD - Preceptor of the Dermatology Service, Marcilio Dias Naval Hospital - HNMD (Hospital Naval Marcílio Dias). Head and professor of the course "Shortcuts in Dermatology" - Rio de Janeiro (RJ), Brazil.

PhD - Professor, School of Medicine, Federal University of Rio de Janeiro (UFRJ) - Professor, Postgraduate Program in Dermatology, Federal University of Rio de Janeiro (UFRJ) - Rio de Janeiro (RJ), Brazil.

PhD - Professor of Dermatology, CEUMA University (Universidade CEUMA) - São Luis (MA), Brazil.

M.Sc. - MD; PhD student, Postgraduate Program in Dermatology, School of Medicine, Federal University of Rio de Janeiro (UFRJ) - Rio de Janeiro (RJ), Brazil

PhD - Postdoctoral degree; Professor of Dermatology, School of Medical Sciences - State University of Rio de Janeiro (UFRJ). Professor, Postgraduate Program in Medicine - Federal University of Rio de Janeiro (UFRJ) - Rio de Janeiro (RJ), Brazil. 


\section{INTRODUCTION}

Cytokines are small polypeptides $(8-80 \mathrm{kD})$ produced in response to antigens, microorganisms or other non-infectious stimuli. They are capable of regulating immune and inflammatory reactions and interacting with the endocrine and nervous systems. Because they are not preformed or stored, they are released in brief, self-limited events as a result of cellular activation after synthesis initiated by gene transcription. They were initially named after their origin, as follows: monokines, derived from mononuclear phagocytes; lymphokines, derived from lymphocytes, and interleukins, produced by leukocytes and acting on them. These terms are not suitable since there is no specificity in relation to production or target cells. The actions of cytokines are oftentimes redundant and pleiotropic, and the same occurs with tumor necrosis factor-alpha (TNF- $\alpha$ ). Pleiotropism refers to the ability of a cytokine to act on different cell types. TNF- $\alpha$ binds to receptors that are present on virtually all cells of the body, acting on the same cell that produced it (autocrine action), on immediate neighbor cells (juxtacrine action), on cells that neighbor the cells of origin (paracrine action), or on distant target cells (endocrine action). The regulation of target cells is modified by external signals; for example, when $\mathrm{T}$ lymphocytes are stimulated by antigens, there is increased expression of some cytokine receptors such that antigen-specific lymphocytes are the preferred responder cells (self- regulated mechanism). ${ }^{1}$

All cytokine receptors consist of one or more transmembrane proteins. The extracellular portion binds to the cytokine and the intracytoplasmic portion initiates the signaling pathways. Even though most cells express low levels of receptors for a cytokine, its binding to a specific receptor shows high affinity and is capable of triggering its various biological effects, such as lymphocyte differentiation into Th1, Th2 or Th17 cells, cell proliferation or apoptosis. Despite the lack of similarity between most individual cytokines in relation to gene or protein sequencing, they can be divided into groups according to their biological actions, as follows: (1) mediators of innate immunity, (2) mediators of adaptive immune response, and (3) stimulators of bematopoiesis. They can also be classified according to similarities in the structure and sequence of their receptors, which originates the superfamilies of receptors. ${ }^{2}$ Regardless of the classification, different cytokines may share receptor subunits, thus the formation of a network and functional redundancy.

Autoimmune diseases and inflammatory reactions mediated by T-helper cells can be either Th1 (T helper lymphocytes) or Th2. ${ }^{3}$ This division is based mainly on the relationship between levels of IFN-g and IL- 4 produced by a given T lymphocyte clone, directly quantified in tissues or in vitro. ${ }^{4}$ In general, there is increased production of Th2 cytokine profile and increased IL- 4 and IL-10 in Graves' disease, atopic dermatitis and lepromatous leprosy. Through this pathway, there is increased humoral immunity (antibodies), increased IgE production and slowed Th1 response. ${ }^{5}$ However, in delayed hypersensitivity reaction, tuberculous leprosy, rheumatoid arthritis, Crohn's disease and psoriasis, there is dysregulated lymphocyte response with increased Th1 proinflammatory cytokines (high IFN- $\gamma$ and TNF- $\alpha$ ), at the expense of regulatory Th2 cytokines (Chart 1). 6,7 The pattern of cytokines observed in psoriatic skin lesions shows increased expression of IL-1, IL-2, IL-6, IL-8, IL-12, TNF- $\alpha$, IFN-gamma, transforming growth factor alpha and beta (TGF-a and TGF b), and granulocyte-macrophage colony-stimulating factor (GMCSF) (Figure 1). ${ }^{8-13}$

The role of IL-17, as a proinflammatory cytokine, and of IL-23, responsible for expanding and maintaining the Th17 pathway, has become more important in the context of various inflammatory diseases, including autoimmune diseases. This "new" pathway has been the subject of many studies because of its relevance in the development and maintenance of psoriasis. Th17 cells mainly produce IL-6, IL-17 and IL-22.

Wolk et al. studied the expression of 20 cytokines in psoriatic lesions. They showed that among all the cytokines investigated, IL-22 and IL-17 levels were higher. ${ }^{14}$ The expression of IL-22 was correlated with disease severity and was approximately 10 times greater than that of IFN-gamma. ${ }^{14} \mathrm{IL}-22$ is generally produced by activated T cells and Natural Killer cells (NK),

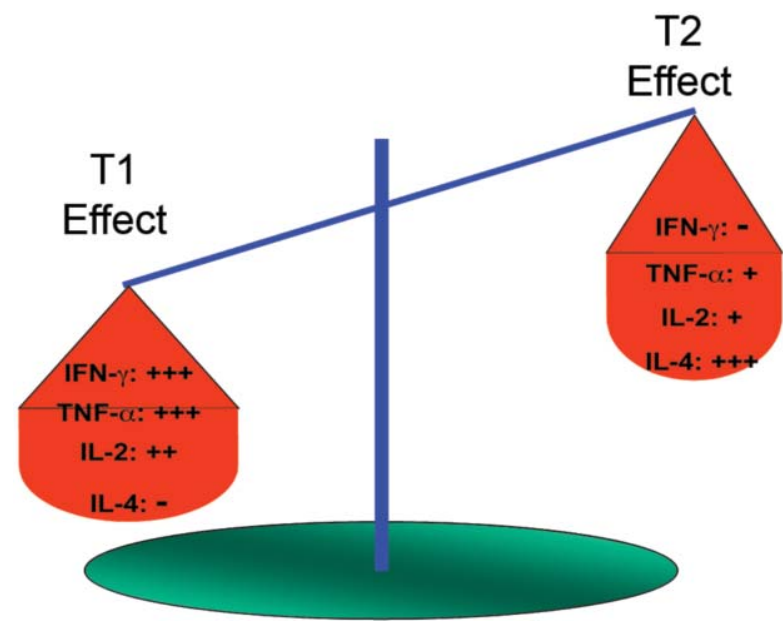

FIGURE 1: Lymphocytic balance in the release of cytokines. Increased production of Th1 cytokine profile in psoriasis 
Chart 1: Profile of lymphocytic response in some diseases

\begin{tabular}{|ll|}
\hline $\begin{array}{l}\text { Diseases with a predominantly } \\
\text { Th1 cytokine profile }\end{array}$ & $\begin{array}{l}\text { Diseases with a predominantly } \\
\text { Th2 cytokine profile }\end{array}$ \\
$\begin{array}{ll}\text { Delayed Cellular Hypersensitivity } \\
\text { Psoriasis }\end{array}$ & $\begin{array}{l}\text { Graves' disease } \\
\text { Atopic dermatitis }\end{array}$ \\
Tuberculoid Leprosy & Lepromatous leprosy \\
Mycosis fungoides & Asthma \\
Acute graft-versus-host disease & Chronic graft-versus-host disease \\
Rheumatoid arthritis & \\
Reactive arthritis & \\
Crohn's disease & \\
\hline
\end{tabular}

but not by other immune cells or tissues. The major source of IL-22 in psoriatic lesions appears to be effector memory T cells of the two subsets, Th1 and Th $17 .{ }^{15}$

\section{THE CYTOKINE NETWORK}

It can be said that it is a "jumble" of cytokines, due to redundancy, synergism and pleiotropism. This hinders understanding, in a liner fashion, of the mechanism of development of psoriatic lesions (Figure 2). In any case, some key functions should be highlighted. Interleukin-1 (IL-1) was cloned in 1980 and quickly stood out in the regulation of inflammatory processes. Similarly to TNF- $\alpha$, it is also called a primary cytokine, since it can independently initiate a number of mechanisms capable of triggering inflammation. ${ }^{1}$ keratinocytes are the main producers of IL-1 in the skin. Once released, IL-1 can stimulate angiogenesis, increase the expression of adhesion molecules, activate $\mathrm{T}$ cells, induce the synthesis of other cytokines such as TNF- $\alpha$, IL-6, IL-8, IFN- $\gamma$, GM-CSF, and promo- te keratinocyte proliferation. After trauma to the skin, there is local release of cytokines by keratinocytes, leading to the development of new psoriatic lesions in some patients (isomorphic Koebner phenomenon). ${ }^{16,17}$ IL-1 may regulate 388 genes, including those associated with proteolysis, cell adhesion, signal transduction, and aberrant epidermal differentiation observed in psoriasis. ${ }^{18}$

In fact, the denomination IL-1 refers to two cytokines, interleukin 1 alpha (IL-1 $\alpha$ ) and interleukin 1 beta (IL-1 $\beta$ ). Although they have similar actions and bind to the same receptor, they are encoded by distinct genes. ${ }^{19} \mathrm{IL}-1 \alpha$ is expressed as an intracellular protein and is released during mechanical stress or any event that leads to local inflammation of the keratinocyte. IL- $1 \beta$ is synthesized as an inactive molecule and secreted into surrounding tissue or the bloodstream after caspase- 1 cleavage. ${ }^{20}$

Local activation of lymphocytes at sites of injury seems to be the central alteration of psoriasis, and

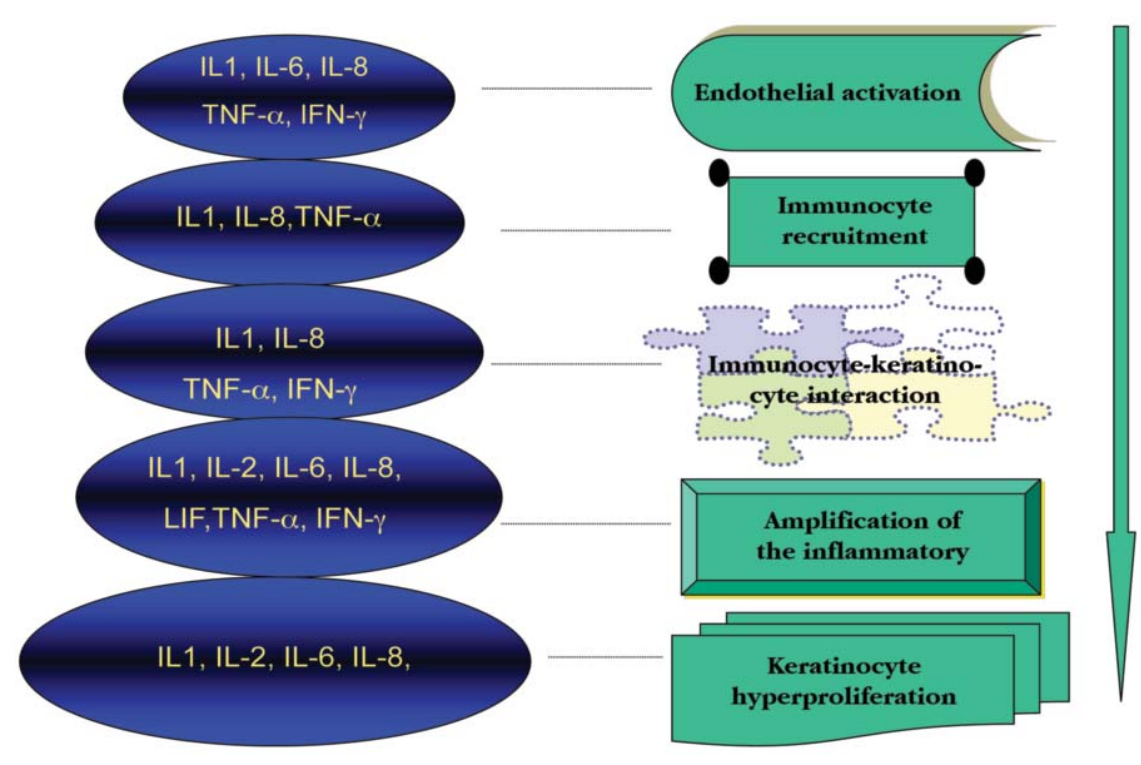

FiguRE 2: Step-by-step participation of cytokines in the physiopathogenesis of psoriasis, culminating in the clinical expression of the disease. With each manifestation, the main cytokines involved are listed. Due to pleiotropism and induction of their activity, a conclusive and limited classification cannot be presented 
its influx precedes neutrophil infiltration. The interaction between $T$ cells and keratinocytes is important in the pathogenesis of psoriasis due to secretion of proinflammatory cytokines and growth factors in psoriatic skin. Interleukin-2 (IL-2) acts specifically as a lymphocyte growth factor and is increased in psoriatic plaques. ${ }^{11}$ The IL-2 receptor is expressed in activated $\mathrm{T}$ cells and can be measured as a soluble protein (sIL $-2 \mathrm{R})$. Zalewska et al. demonstrated increased levels of sIL-2R in the plasma of patients with psoriasis, which was positively correlated with the PASI, and their reduction was positively correlated with clinical improvement. ${ }^{21}$

Interleukin 6 (IL-6) is also a pleiotropic cytokine. Among its typical actions are regulation of the expression of other cytokines, cell proliferation and differentiation and inhibition of tumor growth, as well as induction of acute-phase proteins in the inflammatory reaction. IL-6 is present in normal human skin and is immunologically detected in basal keratinocytes, endothelial cells, fibroblasts and mononuclear cells. ${ }^{22}$

IL- 6 acts as an autocrine mitogen in psoriatic epidermis. It acts in synergy with IL-1 and TNF- $\alpha$ contributing to cellular hyperproliferation through its action on the epidermal growth factor receptor (EGF). ${ }^{22}$ Goodman et al. observed increased IL-6 levels in psoriatic lesions, compared to the normal skin of healthy volunteers. On confocal immunofluorescence microscopy, they observed increased expression of the cytokine at the top of the dermal papillae and in the superficial vascular plexus. They also observed that IL6 colocalizes with $\mathrm{CD} 45^{+}$and IL-17. ${ }^{23}$ In the evaluation of 219 patients, Alenius et al. positively correlated IL-6 levels with arthritis, especially in patients with increased C-reactive protein, confirming its involvement in systemic and acute inflammation. ${ }^{24}$ Similarly, the clinical improvement observed following the use of etanercept is associated with a marked reduction in IL-6 expression (greater than the reduction of TNF-a). ${ }^{25}$ In another study, Koshiba et al. investigated epithelial crypt cells of the amygdale of 36 patients with palmoplantar pustulosis (pustular psoriasis of Barber) and observed a significant increase in IL- 6 and p53 transcription factors. ${ }^{26}$

Very interesting observations associate cytokines with other co-morbidities in psoriasis. ${ }^{27-29}$ Both depression and obesity are associated with increased IL-6 and IL-1. With regard to the relationship between IL- 6 and glucose metabolism, Senn et al. and Rotter et al. showed, respectively, reduced insulin action in hepatocytes and adipocytes after exposure to IL-6. ${ }^{30,31}$ Accordingly, circulating levels of IL-6 in type 2 diabetic patients and/or obese patients are approximately two to three times greater than those observed in healthy individuals. ${ }^{32}$
IL-8 plays an important role in attracting neutrophils. It also promotes keratinocyte proliferation and stimulates angiogenesis, with an increase in the expression of its receptors in injured skin. ${ }^{33}$ High levels of IL-8 were detected in situ and in the serum of some patients with psoriasis. ${ }^{34}$ Neutrophil recruitment has traditionally been attributed to IL- 8 production by keratinocytes. However, a recent study suggests that $\mathrm{T}$ cells may also be involved in IL- 8 production. In fact, IL-8 would be one of the connecting bridges between these inflammatory cells, lymphocytes and neutrophils. Ferran et al. demonstrated that lymphocytes that selectively migrate to the skin $\left(\mathrm{CLA}^{+}\right)$ secrete IL-8, which could contribute to the formation of Munro's microabscesses and spongiform pustules of Kogoji through chemotactic action on neutrophils. $^{35}$

The term interferon (IFN) derives from the ability that these cytokines have to "interfere" with viral replication in host cells. This action is primarily paracrine and team-like. For example, a cell infected by a virus secretes IFN to protect uninfected neighboring cells and inhibits viral replication in the cell itself, in an autocrine manner. These mechanisms are well known by dermatologists, both due to indirect increase of INF in tissues, with the use of Imiquimod (treatment of flat warts and molluscum contagiosum), or direct increase through the use of intralesional interferon in the treatment of resistant warts. ${ }^{36}$ IFN- $\gamma$ activates Langerhans cells, increases ICAM expression in endothelial cells and keratinocytes, and cooperates with TNF- $\alpha$ (synergistic effect) increasing the production of IL-8 and release of IL-1.

All three IFNs (alpha, beta and gamma) have different properties and may act synergistically or antagonistically. They all increase the activity of natural killer lymphocytes and stimulate the synthesis of arachidonic acid products, which could explain the worsening of psoriasis caused by the therapeutic use of these cytokines. ${ }^{37}$ Therefore, the use of IFN- $\alpha$ in the treatment of hepatitis $\mathrm{C}$ has been implicated in the onset of psoriasis. Some patients had no personal or familial history of the disease. Moreover, a chronological relationship between the discontinuation of treatment and improvement of skin lesions was observed. ${ }^{38-40}$

Intradermal injection of IFN- $\gamma$ in the healthy skin of patients with psoriasis has led to the appearance of erythematous, scaly plaques in loco. ${ }^{41}$ Another classic example already mentioned is the aggravation of psoriasis due to the use of imiquimod. ${ }^{42}$

Not long ago, the pathogenesis of psoriasis was basically explained by the production of Th1 cells; however, there has been greater involvement of Th17 cells that produce IL-17 and IL-22. ${ }^{43,44}$ These cells are defined by their ability to synthesize IL-17 in response 
to antigen-presenting cells, IL-23 and other differentiation cytokines. ${ }^{45-48}$ IL-23, a cytokine produced by macrophages and dendritic cells, leads to expansion of Th17 cells, which are differentiated from naive T cells in the presence of IL- 6 and transforming growth factor beta (TGF- $\beta$ ). ${ }^{49,50}$ Some studies indicate that IL22 , produced by effector Th17 lymphocytes, acts on keratinocytes, which contributes to the amplification and maintenance of the inflammatory response. ${ }^{51}$ The molecule CD161 has been recently described as a new cell surface marker for Th17 in human cells. ${ }^{52}$

The cytokines IL-12 and IL-23 are critical for the perpetuation of psoriatic lesions. The former contributes to the production of IFN- $\gamma$ and maintenance of Th1 response, and the latter perpetuates Th17 response. Both IL-12 and IL-23 are heterodimers and share a subunit denominated $\mathrm{p} 40$. Binding with receptor IL-12R $\beta 1$ occurs through this subunit. The therapeutic use of a monoclonal antibody (ustekinumab), inhibitor of this subunit - convergence point of Th1 and Th17 pathways - has shown a therapeutic response comparable to that of TNF- $\alpha$ inhibitors. ${ }^{53}$

TNF- $\alpha$ is the most studied cytokine due to its increased expression in skin lesions and in the serum of patients with pustular lesions, in the synovial fluid of patients with psoriatic arthritis and, above all, due to the therapeutic efficacy of its specific inhibitors (fusion proteins, monoclonal antibodies). ${ }^{54-60}$

In biology, as in many areas of scientific research, completely different areas converge when a simple principle underpins two seemingly different phenomena; in this case, infection and neoplasia. This convergence occurs several times with TNF- $\alpha$ and its biological functions. This cytokine was indirectly discovered in the nineteenth century. In 1983, a surgeon named William Coley noticed that some cancer patients had tumor necrosis and hemorrhage when they developed a bacterial infection. Hoping to have found a cure for cancer, Coley injected patients with bacterial culture supernatants. Although the tumor regressed, patients suffered severe side effects caused by "Coley's toxins". Separately, in 1892, Richard Pfeiffer attempted to isolate the toxic principle of gram-negative microorganisms, a substance he called "endotoxin" to distinguish it from "proteinaceous exotoxins" (in Weaver et al., 2002). ${ }^{61}$ Half a century later, Shear et al. demonstrated the existence of a substance capable of causing hemorrhagic necrosis in tumors. This was observed after injection of Serratia marcescens culture supernatants in mice with tumor tissue implants with sarcomatous degeneration. ${ }^{62} \mathrm{~A}$ serum factor that caused severe weight loss in patients with advanced cancer and severe infection was named cachexin and, soon after, it was observed that this substance was identical to TNF- $\alpha .^{63}$
The TNF- $\alpha$ gene was cloned in the 80s. It is located on the short arm of chromosome 6, next to the Major Histocompatibility Complex (MHC). It has 4 exons and 3 kilobases. Mature TNF- $\alpha$ shares 28\% amino acid sequence homology with another cytokine, lymphotoxin (TNF- $\beta$ ). They also share some biological activities and can compete for the same receptor. ${ }^{64}$ The biological functions of TNF- $\alpha$ are also confused with the activities of another $17 \mathrm{kD}$ cytokine, IL-1, which is structurally different and does not compete for the same receptor.

Monocytes and macrophages are the main cells related to the production of TNF- $\alpha$, but other immune cells are also capable of synthesizing it such as NK cells, basophils, eosinophils, neutrophils and $\mathrm{T}$ and $\mathrm{B}$ lymphocytes, as well as other nonimmune cells - astrocytes, glial cells, neurons, osteoblasts, melanocytes, smooth muscle cells, and spermatogenic and tumoral cells. ${ }^{65,66}$ Constitutionally or by stimulation, it can be produced by almost all cells of the skin, such as keratinocytes, Langerhans cells and other dendritic cells, activated $\mathrm{T}$ cells, macrophages, fibroblasts and endothelial cells. ${ }^{25}$ Gene transcription for TNF- $\alpha$ is "precocious and immediate"; thus, after a signal has been given, TNF levels rapidly increase between 15 and 30 minutes. ${ }^{67}$

This polypeptide is a primary mediator in infection, trauma, and inflammation, as well as in host defense and tissue homeostasis. Depending on its concentration, duration of cell exposure and presence of other cell mediators, its network of biological effects can bring local or systemic benefits or harm. It should be noted that its functions permeate health (equilibrium) and disease. Therefore, TNF- $\alpha$ (1) modulates cell growth, differentiation and metabolism; (2) leads to cachexia by inhibiting stimulation of liver lipogenesis and stimulating lypolysis (3) initiates apoptosis of degenerated cells, neoplastic cells or virus-infected cells, and (4) produces inflammation. ${ }^{64}$ Not surprisingly, its expression and activity are finely regulated at different levels, which allows the quiet work of the TNF-a gene in the absence of exogenous stimulation (Charts 2 and 3).

The main physiological function of TNF- $\alpha$ is to stimulate leukocyte recruitment to sites of infection by increasing adhesion molecules in endothelial cells, making the vascular surface more adherent. This entire sequence is critical for the local response to microorganisms. There is induction of IL-12 and IL-18 synthesis. They are potent cytokines that stimulate the formation of IFN- $\gamma$, which is essential for the elimination of pathogens, especially intracellular ones. It can be concluded that patients taking TNF- $\alpha$ inhibitors are more susceptible to development of Mycobacterium tuberculosis and viral infections. Secondary mediators 
CHART 2: Mechanisms implicated in the induction of TNF- $\alpha$ production

Viral, bacterial, parasitic infection

Tumor cells

Cytokines: IL-1 $\beta$, IL-2, IFN- $\gamma$, GM-CSF, M-CSF, TNF- $\alpha$

Trauma

Liposaccharide

Ultraviolet radiation

Immunological synapse (Langerhans and T cells)

Ultraviolet radiation

induced by systemic administration of TNF- $\alpha$ include cytokines [IL-2, IL- 4 , IL-10, IL-12, IL-18, IFN- $\gamma$, TGF- $\beta$, leukemia inhibitory factor (LIF), macrophage migration inhibitory factor (MIF)], hormones (cortisol, epinephrine, glucagon, insulin), acute-phase proteins, leukotrienes, oxygen free radicals, nitric oxide and prostaglandins. ${ }^{67}$

TNF- $\alpha$ gene polymorphism (already studied in a sample of Brazilian patients with psoriasis), as well as some exogenous stimuli, can be correlated with aggravation or onset of diseases. ${ }^{68}$ In septic shock, serum concentration of TNF- $\alpha$ may be a marker of the severity of gram-negative bacteria infection, since bacterial lipopolysaccharide (LPS or endotoxin) is the most potent stimulus for its release. ${ }^{69}$ TNF- $\alpha$ increases prostaglandin synthesis by hypothalamic cells. This leads to fever, and TNF- $\alpha$ is considered an endogenous pyrogen. Increase in body temperature is related to increased prostaglandin synthesis by hypothalamic cells. TNF- $\alpha$ also inhibits thrombomodulin, an inhibitor of coagulation, contributing to disseminated intravascular coagulation. Concomitantly, there is reduced cardiac contractility and vascular tone resulting in
Chart 3: Some TNF- $\alpha$ inhibitors

Corticosteroids

Cytokine: IL-10

Increased soluble receptors

Monoclonal Anti-TNF- $\alpha$ antibodies

Anti-TNF- $\alpha$ fusion proteins

Thalidomide

Pentoxifylline

lower blood pressure. Cachexia is associated with prolonged exposure to TNF- $\alpha$, which generates a catabolic state due to increased glycogenolysis and lypolysis, aggravated by anorexia (Graph 1). ${ }^{6}$

With regard to psoriasis, TNF- $\alpha$ has different effects on the cellular level, which correlate with the pathophysiological mechanisms of the disease. It has been shown that TNF- $\alpha$ is capable of increasing production of several pro-inflammatory cytokines synthesized by activated lymphocytes or keratinocytes, exerting specific effects. IL-1 stimulates the synthesis of more cytokines and the expression of cytokeratin 6 (CK6), a marker of activated and hyperproliferative keratinocytes. TNF- $\alpha$ has a direct effect on CK6 increase through stimulation of its gene promoter of transcription factors in keratinocytes, making the epithelium hyperproliferative. IL- 6 and TNF- $\alpha$ are redundant in various functional aspects, both by stimulating the production of acute-phase proteins and increasing the speed of erythrocyte sedimentation, which can be observed in erythrodermic patients with the generalized pustular form of the disease, and also for increasing keratinocyte proliferation. ${ }^{70}$ The two cytokines are found in high concentrations in patients with pso-

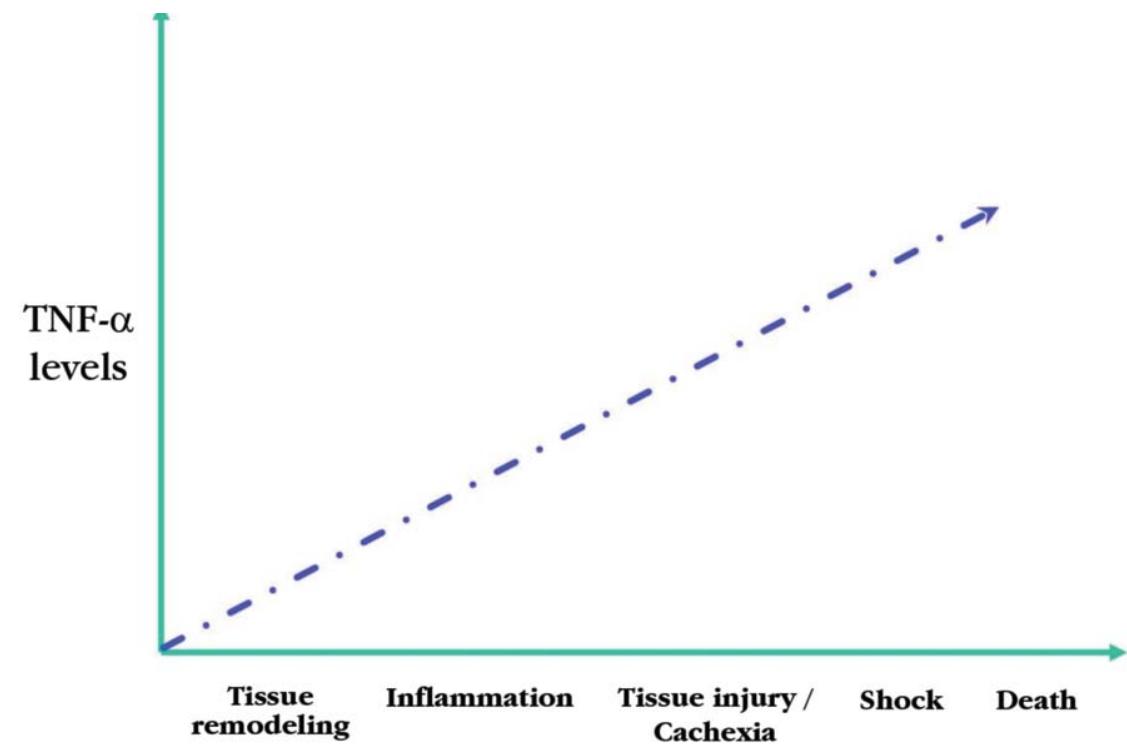

GraPH 1: Biological Activities of TNFalpha; based on its levels on tissues, it can act as a defender or cause tissue injury 
CHART 4: Clinical and histopathological correlation associated with cytokines in the formation of psoriatic plaques

\begin{tabular}{|lll|}
\hline Symptoms & Histopathology & Cytokine (s) \\
$\begin{array}{l}\text { Stratified psoriatic scales } \\
\text { Candle-wax stain }\end{array}$ & $\begin{array}{l}\text { Hyperkeratosis } \\
\text { Parakeratosis }\end{array}$ & $\begin{array}{l}\text { IL-1: keratinocyte proliferation } \\
\text { IL-6: keratinocyte proliferation }\end{array}$ \\
Psoriatic plaques & Acanthosis & TNF- $\alpha$ : through NF- $\kappa$ B, it inhibits \\
& kyperplasia with proliferation \\
of interpapillary cones & IL-1 e TNF- $\alpha$ : increased \\
& & hyperproliferative keratin, CK6 \\
Erythema & Dilation, corkscrew capillary & IL-1: stimulates angiogenesis \\
& Lymphocytic inflammatory infiltrate & IL-2: lymphocytic proliferation \\
& & IL-23: maintenance of \\
inflammatory response \\
TNF- $\alpha:$ increased ICAM
\end{tabular}

riasis. Interleukin 8 (IL-8) is involved in lymphocyte activation and neutrophil chemotaxis, cells that are present in Munro's and Kogoj microabscesses, typical of the disease. TNF- $\alpha$ may also increase the action of NF- $\kappa B$ by increasing degradation of $I-\kappa B$, its inhibitory protein. NF- $\mathrm{KB}$ is a nuclear transcription factor of cytokines such as TNF- $\alpha$, IL- 6 and IL-8, and also of ICAM1, VCAM-1 and E-selectin. When stimulated, it enhances inflammatory response and inhibits apoptosis of keratinocytes. ${ }^{71}$

TNF- $\alpha$ also leads to increased vasoactive intestinal peptide receptors. This promotes an increase of inflammatory cytokines and keratinocyte prolifera- tion. It also stimulates the formation of vascular endothelial-derived growth factor (VEGF) by increasing the production of nitric oxide. ${ }^{72}$

Location in the tissue and the strategic mobility of dendritic cells are essential for communication between the microenvironments of the epidermis and dermis. This migration is one of the earliest mechanisms in the generation of an inflammatory response that can be influenced by several factors. E-cadherin is a selective intercellular adhesion molecule present in all layers of the epidermis. The inhibition of its expression, mediated by TNF- $\alpha$, facilitates the migration of Langerhans cells, and this may increase immune response. ${ }^{73}$

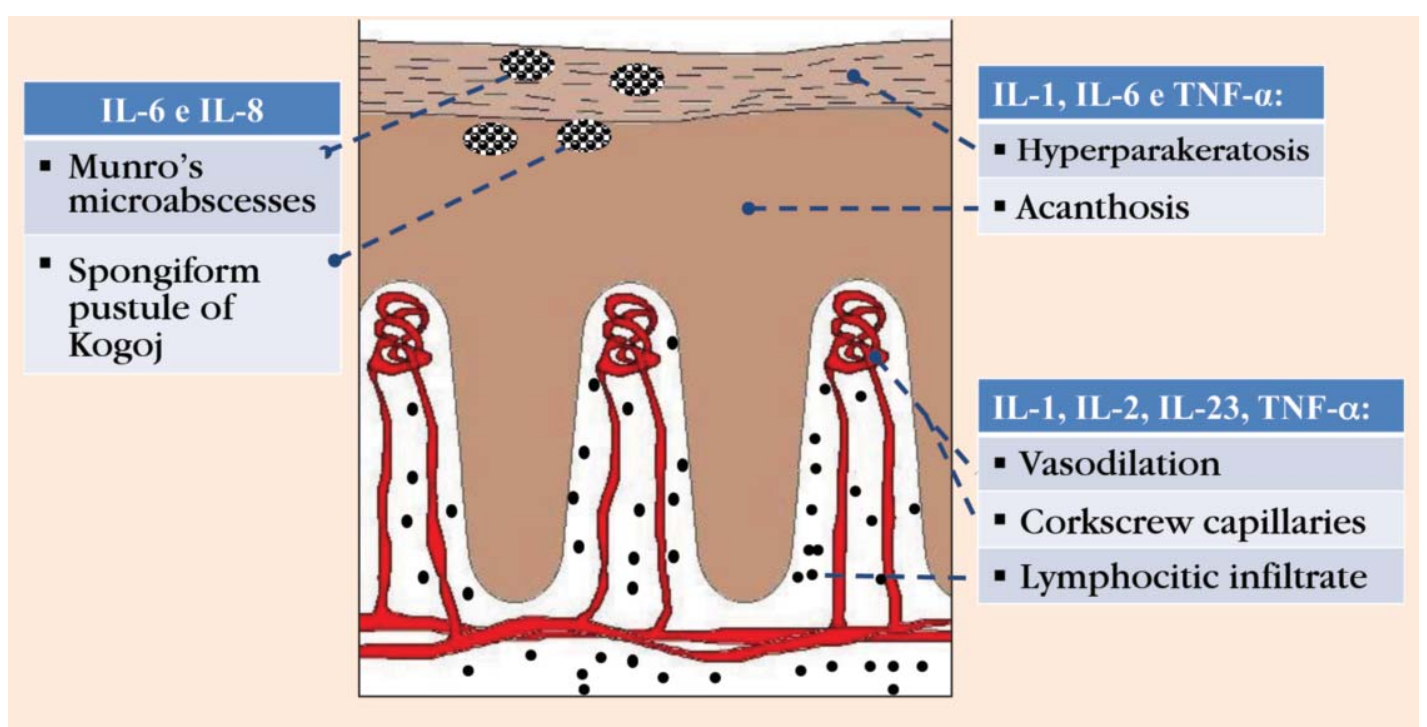

Figure 3: In the drawing scheme: Clinical and histopathological correlation associated with cytokines in the formation of psoriatic plaques 


\section{THE PSORIATIC PLAQUE}

We can establish a correlation between clinical, histopathological and immunological responses through mechanisms currently associated with cytokines in the communication between resident cells (keratinocytes and endothelial cells) and infiltrating cells (lymphocytes, neutrophils and Langerhans cells) of psoriasis. Increased cell renewal and incomplete keratinocyte maturation are related to acanthosis and hyperparakeratosis, whose clinical symptoms are the development of plaques with stratified scales that peel-off by curettage (candle-wax stain). Both IL-1 and IL-6 increase keratinocyte proliferation. In an additive manner, TNF- $\alpha$ increases NF-kB levels, inhibits apoptosis and stimulates transcription of the hyperproliferative cytokeratin CK6. Erythema secondary to vascu- lar proliferation and inflammatory infiltration are mediated by IL- 1 and TNF- $\alpha$, which activate endothelial cells by increasing ICAM and stimulate angiogenesis, a process maintained by IL-22. IL-8 secreted by activated lymphocytes in psoriasis stimulates neutrophil chemotaxis, cells that can accumulate in the epidermis, especially when there are pustular lesions, forming the spongiform pustule of Kogoj (Chart 4 and Figure 3).

Extrapolation of the results obtained from the measurement of cytokines in vitro and in vivo must be done with extreme caution. We must keep in mind that these results may fluctuate due to the use of different tests, different stages of the disease, demographic differences, and coexisting diseases.

\section{REFERENCES}

1. Steinhoff M, Luger TA. The skin cytokine network. In: Bos JD, editor. Skin Immune System. Cutaneous Immunology and Clinical Immunodermatology. 3rd ed. Boca Raton, Florida: CRC Press; 2005. p.349-72.

2. Abbas AK, Lichtman AH. Citocinas. In: Abbas AK. Imunologia celular e molecular. 5 ed. São Paulo: Elsevier; 2005. p. 251-82.

3. Mosmann TR, Sad S. The expanding universe of T-cell subsets: Th1, Th2 and more. Immunol Today. 1996;17:138-46.

4. Salgame P, Abrams JS, Clayberger C, Goldstein H, Convit J, Modlin RL, et al. Differing lymphokine profiles of functional subsets of human CD4 and CD8 T cell clones. Science. 1991;254:279-82.

5. Sampaio SAP, Rivitti EA. Imunopatologia cutânea. In: Sampaio SAP, Rivitti EA Dermatologia. 3 ed. São Paulo: Artes Médicas; 2007. p.45-76.

6. Najarian DJ, Gottlieb AB. Connections between psoriasis and Crohn's disease. J Am Acad Dermatol. 2003;48:805-21

7. Salomão Barreto MA, Vianna SV, Brotas A, Pessanha F, Carneiro SCS. Terapia biológica no tratamento da psoríase e da artrite psoriásica. In: 60 Congresso Brasileiro de Dermatologia; 2005; Brasília - DF, Brasil. Rio de Janeiro: Anais Brasileiros de Dermatologia; 2005. p.202.

8. Grossman RM, Krueger J, Yourish D, Granelli-Piperno A, Murphy DP, May LT, et al Interleukin 6 is expressed in high levels in psoriatic skin and stimulates proliferation of cultured human keratinocytes. Proc Natl Acad Sci U S A. 1989;86:6367-71.

9. Barker JN, Sarma V, Mitra RS, Dixit VM, Nickoloff BJ. Marked synergism between tumor necrosis factor-alpha and interferon-gamma in regulation of keratinocytederived adhesion molecules and chemotactic factors. J Clin Invest. 1990;85:605-

10. Gomi T, Shiohara T, Munakata T, Imanishi K, Nagashima M. Interleukin 1 alpha, tumor necrosis factor alpha, and interferon gamma in psoriasis. Arch Dermatol. 1991;127:827-30

11. Uyemura K, Yamamura M, Fivenson DF, Modlin RL, Nickoloff BJ. The cytokine network in lesional and lesion-free psoriatic skin is characterized by a T-helper type 1 cell-mediated response. J Invest Dermatol. 1993:101:701-5.

12. Vollmer S, Menssen A, Trommler P, Schendel D, Prinz JC. T lymphocytes derived from skin lesions of patients with psoriasis vulgaris express a novel cytokine pattern that is distinct from that of T helper type 1 and T helper type 2 cells. Eur $\mathrm{J}$ Immunol. 1994;24:2377-82.

13. Olaniran AK, Baker BS, Paige DG, Garioch JJ, Powles AV, Fry L. Cytokine expression in psoriatic skin lesions during PUVA therapy. Arch Dermatol Res. 1996;288:421-5

14. Wolk K, Kunz S, Witte E, Friedrich M, Asadullah K, Sabat R. IL-22 increases the innate immunity of tissues. Immunity. 2004:21:241-54.
15. Chung $Y$, Yang $X$, Chang $S H, M a ~ L$, Tian $Q$, Dong C. Expression and regulation of IL-22 in the IL-17-producing CD4 + T Iymphocytes. Cell Res. 2006:16:902-7.

16. Sanchez APG. Imunopatogênese da psoríase. An Bras Dermatol. 2010;85:747-9.

17. Boyd AS, Neldner KH. The isomorphic response of Koebner. Int J Dermatol. 1990;29:401-10

18. Yano S, Banno T, Walsh R, Blumenberg M. Transcriptional responses of human epidermal keratinocytes to cytokine interleukin-1. J Cell Physiol. 2008;214:1-13.

19. Gabay C, Lamacchia C, Palmer G. IL-1 pathways in inflammation and human diseases. Nat Rev Rheumatol. 2010;6:232-41.

20. Sanmiguel JC, Olaru F, Li J, Mohr E, Jensen LE. Interleukin-1 regulates keratinocyte expression of $T$ cell targeting chemokines through interleukin-1 receptor associated kinase-1 (IRAK1) dependent and independent pathways. Cell Signal. 2009;21:685-94

21. Zalewska A, Głowacka E, Wyczółkowska J, Tchórzewski H, Narbutt J, SysaJędrzejowska A. Interleukin 6 and 8 Levels in Plasma and Fibroblast Cultures in Psoriasis. Mediators Inflamm. 2006;2006:81767.

22. Castells-Rodellas A, Castell JV, Ramirez-Bosca A, Nicolas JF, Valcuende-Cavero F, Thivolet J. Interleukin-6 in normal skin and psoriasis. Acta Derm Venereol. 1992;72:165-8.

23. Goodman WA, Levine AD, Massari JV, Sugiyama H, McCormick TS, Cooper KD. IL-6 Signaling in Psoriasis Prevents Immune Suppression by Regulatory T Cells1. J Immunol. 2009:183:3170-6.

24. Alenius GM, Eriksson C, Rantapää Dahlqvist S. Interleukin-6 and soluble interleukin-2 receptor alpha-markers of inflammation in patients with psoriatic arthritis? Clin Exp Rheumatol. 2009:27:120-3.

25. Cordiali-Fei P, Ardigò M, Mastroianni A, Giuliani A, D' Agosto G, Bordignon V, et al. Serum cytokines and bioumoral immunological characterization of psoriatic patients in long term etanercept treatment. Int $\mathrm{J}$ Immunopathol Pharmacol. 2008:21:643-9.

26. Koshiba S, Ichimiya S, Nagashima T, Tonooka A, Kubo T, Kikuchi T, et al. Tonsillar crypt epithelium of palmoplantar pustulosis secretes interleukin- 6 to support B-cell development via p63/p73 transcription factors. J Pathol. 2008;214:75-84.

27. Howren MB, Lamkin DM, Suls J. Associations of depression with C-reactive protein, IL-1, and IL-6: a meta-analysis. Psychosom Med. 2009;71:171-86.

28. Pereira FSM. Perfil Lipídico dos pacientes com psoríase do Hospital Universitário Clementino Fraga Filho da Universidade Federal do Rio de Janeiro [dissertação]. Rio de Janeiro (RJ): Universidade Federal do Rio de Janeiro; 2008.

29. Duarte GV, Follador I, Cavalheiro CM, Silva TS, Oliveira Mde F.Psoriasis and obesity: literature review and recommendations for management. An Bras Dermatol. 2010;85:355-60 
30. Senn JJ, Klover PJ, Nowak IA, Mooney RA. Interleukin-6 induces cellular insulin resistance in hepatocytes. Diabetes. 2002;51:3391-9.

31. Rotter V, Nagaev I, Smith U. Interleukin-6 (IL-6) induces insulin resistance in 3T3L1 adipocytes and is, like IL-8 and tumor necrosis factor- $\alpha$, overexpressed in human fat cells from insulin-resistant subjects. J Biol Chem. 2003;278:45777-84.

32. Kolb H, Mandrup-Poulsen T. An immune origin of type 2 diabetes. Diabetologia. 2005;48:1038-50.

33. Beljaards RC, Van Beek P, Nieboer C, Stoof TJ, Boorsma DM. The expression of interleukin-8 receptor in untreated and treated psoriasis. Arch Dermatol Res. 1997;289:440-3.

34. Arican 0, Aral M, Sasmaz S, Ciragil P. Serum levels of TNF- $\alpha$, IFN- $\gamma$, IL-6, IL-8, IL$12, \mathrm{IL}-17$, and IL-18 in patients with active psoriasis and correlation with disease severity. Mediators Inflamm. 2005;2005:273-9.

35. Ferran M, Galván AB, Giménez-Arnau A, Pujol RM, Santamaría-Babi LF. Production of interleukin 8 by circulating CLA + T cells with skin tropism in patients with psoriasis and in healthy controls. Actas Dermosifiliogr. 2010;101:151-5

36. Czelusta AJ, Evans T, Arany I, Tyring SK. A guide to immunotherapy of genital warts: focus on interferon and imiquimod. BioDrugs. 1999;11:319-32.

37. Boraschi D, Censini S, Bartalini M, Tagliabue A. Regulation of arachidonic acid metabolism in macrophages by immune and nonimmune interferons. J Immunol. 1985;135:502-5.

38. Yurci A, Guven K, Torun E, Gursoy S, Baskol M, Akgun H, et al. Pyoderma gangrenosum and exacerbation of psoriasis resulting from pegylated interferon alpha and ribavirin treatment of chronic hepatitis C. Eur J Gastroenterol Hepatol. 2007;19:811-5

39. Horev A, Halevy S. New-onset psoriasis following treatment with pegylated interferon-alpha 2b and ribavirin for chronic hepatitis C. Isr Med Assoc J. 2009;11:760-1.

40. Ketikoglou I, Karatapanis S, Elefsiniotis I, Kafiri G, Moulakakis A. Extensive psoriasis induced by pegylated interferon alpha-2b treatment for chronic hepatitis B. Eur J Dermatol. 2005;15:107-9.

41. Fierlbeck $\mathrm{G}$, Rassner $\mathrm{G}$, Muller C. Psoriasis induced at the injection site of recombinant interferon gamma. Results of immunohistologic investigations. Arch Dermatol. 1990;126:351-5.

42. Gaspari AA. Mechanism of action and other potential roles of an immune response modifier. Cutis. 2007;79(4 Suppl):36-45.

43. Blauvelt $A$. New concepts in the pathogenesis and treatment of psoriasis: key roles for IL-23, IL-17A and TGF-B1. Expert Rev Dermatol. 2007;2:69-78.

44. Bettelli $E$, Oukka M, Kuchroo VK.. T(H)-17 cells in the circle of immunity and autoimmunity. Nat. Immunol. 2007;8:345-50.

45. Chen Y, Langrish CL, McKenzie B, Joyce-Shaikh B, Stumhofer JS, McClanahan T, et al. Anti-IL-23 therapy inhibits multiple inflammatory pathways and ameliorates autoimmune encephalomyelitis. J Clin Invest. 2006;116:1317-26.

46. Bettelli E, Carrier Y, Gao W, Korn T, Strom TB, Oukka M, et al. Reciprocal development pathways for the generation of pathogenic effector Th17 and regulatory $T$ cells. Nature. 2006;441:235-38

47. Chen Z, Tato CM, Muul L, Laurence A, O'Shea JJ. Distinct regulation of interleukin17 in human T helper lymphocytes. Arthritis Rheum. 2007;56:2936-46.

48. Aggarwal S, Ghilardi N, Xie MH, de Sauvage FJ, Gurney AL. Interleukin-23 promotes a distinct CD4 T cell activation state characterized by the production of interleukin-17. J Biol Chem. 2003;278:1910-4.

49. Harrington LE, Hatton RD, Mangan PR, Turner H, Murphy TL, Murphy KM, et al. Interleukin-17 producing CD4 + effector T cells develop via a lineage district from the T helper type 1 and 2 lineages. Nat. Immunol. 2005;6:1123-32.

50. Park H, Li Z, Yang XO, Chang SH, Nurieva R, Wang YH, et al. A distinct lineage of CD4 $T$ cells regulates tissue inflammations by producing inerleukin-17. Nat Immunol. 2005;6:1133-41.

51. Ma HL, Liang S, Li J, Napierata L, Brown T, Benoit S, et al. IL-22 is required for Th17 cell-mediated pathology in a mouse model of psoriasis-like skin inflammation. J Clin Invest. 2008;118:597-607.

52. Cosmi L, De Palma R, Santarlasci V, Maggi L, Capone M, Frosali F, et al. Human interleukin 17-producing cells originate from a CD161+CD4+ T cell precursor. J Exp Med. 2008;205:1903-16.

53. Griffiths CE, Strober BE, van de Kerkhof P, Ho V, Fidelus-Gort R, Yeilding N, et al. Comparison of ustekinumab and etanercept for moderate-to-severe psoriasis. N Engl J Med. 2010;362:118-28.
54. Ettehadi P, Greaves MW, Wallach D, Aderka D, Camp RD. Elevated tumour necrosis factor-alpha (TNF-alpha) biological activity in psoriatic skin lesions. Clin Exp Immunol. 1994;96:146-51.

55. Mussi A, Bonifati C, Carducci M, D'Agosto G, Pimpinelli F, D'Urso D, et al. Serum TNF-alpha levels correlate with disease severity and are reduced by effective therapy in plaque-type psoriasis. J Biol Regul Homeost Agents. 1997;11:115-8.

56. Sagawa Y, Shiohara T, Imanishi K, Nagashima M. Is sustained production of tumor necrosis factor-alpha relevant to the development of pustular psoriasis? Dermatology. 1993;187:81-3.

57. Seishima M, Takemura M, Saito K, Kitajima Y. Increased serum soluble Fas, tumor necrosis factor alpha and interleukin 6 concentrations in generalized pustular psoriasis. Dermatology. 1998;196:371-2

58. Nickoloff BJ. The cytokine network in psoriasis. Arch Dermatol. 1991;127:871-84

59. Partsch G, Steiner G, Leeb BF, Dunky A, Bröll H, Smolen JS. Highly increased levels of tumor necrosis factor-alpha and other proinflammatory cytokines in psoriatic arthritis synovial fluid. J Rheumatol. 1997;24:518-23.

60. Wollina $\mathrm{U}$, Konrad $\mathrm{H}$. Treatment of recalcitrant psoriatic arthritis with anti-tumo necrosis factor-alpha antibody. J Eur Acad Dermatol Venereol. 2002;16:127-9.

61. Weaver AL, Kavanaugh A, Beutler BA, Burmester GR, O'Dell JR. The evolution of biologic DMARD therapy in rheumatoid arthritis management .Medscape [Internet]. [cited $2010 \mathrm{Jul}$ 10]. Available from: http://www.medscape.com/viewprogram/2109

62. Shear MJ, Turner FC, Perrault A. Chemical treatment of tumors. V. Isolation of the hemorrhage-producing fraction from Serratia marcescens (Bacillus prodigiosus) culture filtrate. J Natl Cancer Inst. 1943;4:81-97.

63. Beutler B, Cerami A. Tumor necrosis, cachexia, shock, and inflammation: a common mediator. Annu Rev Biochem. 1988;57:505-18.

64. Tracey KJ, Vlassara $\mathrm{H}$, Cerami A. Cachectin/tumour necrosis factor. Lancet. 1989;1:1122-6.

65. Vassalli $P$. The pathophysiology of tumor necrosis factors. Annu Rev Immunol. 1992;10:411-52.

66. Bazzoni F, Beutler B. The tumor necrosis factor ligand and receptor families. N Engl J Med. 1996:334:1717-25.

67. Schottelius AJ, Moldawer LL, Dinarello CA, Asadullah K, Sterry W, Edwards CK 3rd. Biology of tumor necrosis factor-alpha- implications for psoriasis. Exp Dermatol. 2004;13:193-222.

68. Magalhães RF, Biral AC, Pancoto JA, Donadi EA, Mendes CT Jr, Magna LA, et al. Human leukocyte antigen (HLA) and single nucleotide polymorphisms (SNPs) tumor necrosis factor (TNF)-alpha -238 and -308 as genetic markers of susceptibility to psoriasis and severity of the disease in a long-term follow-up Brazilian study. Int J Dermatol. 2010;49:1133-40

69. Tracey KJ, Beutler B, Lowry SF, Merryweather J, Wolpe S, Milsark IW, et al. Shock and tissue injury induced by recombinant human cachectin. Science. 1986;234:470-4

70. Neuner P, Urbanski A, Trautinger F, Möller A, Kirnbauer R, Kapp A, et al. Increased IL-6 production by monocytes and keratinocytes in patients with psoriasis. J Invest Dermatol. 1991;97:27-33.

71. Gottlieb AB. Psoriasis. Immunopathology and immunomodulation. Dermatol Clin. 2001;19:649-57, viii.

72. Sirsjö A, Karlsson M, Gidlöf A, Rollman 0, Törmä H. Increased expression of inducible nitric oxide synthase in psoriatic skin and cytokine-stimulated cultured keratinocytes. Br J Dermatol. 1996;134:643-8

73. Schwarzenberger K, Udey MC. Contact allergens and epidermal proinflammatory cytokines modulate Langerhans cell E-cadherin expression in situ. J Invest Dermatol. 1996;106:553-8.

MAILING ADDRESS:

Arles Martins Brotas

Av. Brigadeiro Trompowsky, $S / N$

Ilba do Fundão

21941-590 Rio de Janeiro, RJ.

E-mail:arlesbrotas@gmail.com

How to cite this article: Brotas AM, Cunha JMT, Lago EHJ, Machado CCN, Carneiro SCS. Tumor necrosis factoralpha and the cytokine network in psoriasis. An Bras Dermatol. 2012;87(5):673-83. 


\section{QUESTIONS}

1. Choose the correct alternative in relation to cytokines:

a) They are high molecular weight polypeptides

b) They are pre-formed and released continuously, but with occasional peaks depending on stimuli such as bacterial infections

c) They have autocrine and juxtacrine action without endocrine function

d) Regardless of classification, different cytokines may have common receptor subunits, hence their functional redundancy and networking

2. In general, autoimmune diseases and inflammatory reactions mediated by lymphocytes are divided into those mediated by Th1 or those mediated by Th2 cells. In this respect, choose the incorrect alternative:

a) This classification is based primarily on the relationship between levels of IFN-gamma and interleukin 4 quantified directly in tissues or by the production disease-mediating cells

b) In diseases with Th1 profile, there is greater production of IFN-gamma to the detriment of IL-4

c) In diseases with a Th2 profile, there is predominance of humoral immunity, increased production of IgE and slowed Th1 response

d) In psoriasis and atopic dermatitis, there is a predominance of Th1 response, which explains the coexistence of the two diseases in many patients

3. The following are diseases with a Th1 cytokine profile, except:
a) Crohn's disease
b) Delayed cellular hypersensitivity
c) Lepromatous leprosy
d) Psoriasis

4. Which are cytokines known to be more important in the development of psoriatic lesions?

a) IL-1, IL-2, IL-6, IL-8, IL-12, IL-17, IL-23, TNF- $\alpha$, IFN- $\gamma$

b) IL-1, IL-2, IL-4, IL-6, IL-8, IL-12, TNF- $\alpha$, IFN- $\gamma$

c) IL-1, IL-2, IL-6, IL-8, IL-10, IL-12, TNF- $\alpha$, IFN- $\gamma$

d) IL-1, IL-4, IL-6, IL-8, IL-10, IL-12, TNF- $\alpha$, IFN- $\gamma$

5. Which is a new lymphocyte activation pathway related to the maintenance of the inflammatory response in psoriasis and other autoimmune diseases?
a) Th1
b) $\mathrm{Th} 2$
c) $\mathrm{Th} 3$
d) Th17

6. Which is the main IL-1-producer cell in the skin?
a) Fibroblast
b) Keratinocyte
c) Langerhans Cell
d) Lymphocyte

7. Which cytokines are key for the maintenance of the Th17 and Th1 pathways, respectively?
a) IL-17 and IL-1
b) IL-23 and IL-12
c) IL-22 and TNF- $\alpha$
d) IL-6 and TNF- $\alpha$

8. Which is an activating cytokine of acute-phase proteins in psoriasis that is increased in obese and diabetic patients?
a) IL-12
b) IL-1
c) IL-10
d) IL-6

9. Which is a neutrophil recruiting cytokine (chemotaxis), possibly associated with the spongiform pustule of Kogoj?
a) IL-17
b) IL-5
c) TNF- $\alpha$
d) IL-8

10. Which is a key cytokine in the defense against intracellular microorganisms?
a) IFN-gamma
b) IL-6
c) IL-8
d) IL-4

11. Which is the inhibitory monoclonal antibody of the shared IL-12 and IL-23 receptor subunit?
a) Ustekinumab
b) Adalimumab
c) Efalizumab
d) Infliximab

12. Which is a cytokine present at high levels in septic shock, a marker of disease severity?
a) IFN-gamma
b) TNF- $\alpha$
c) IL-1
d) IL-6

13. Which cytokine, at high levels for prolonged periods, can lead to fever, asthenia and cachexia?
a) IL-4
b) IL-8
c) TNF- $\alpha$
d) IL-12

14. Among the alternatives below, which is the most important factor for induction of TNF- $\alpha$ release?
a) Trauma
b) Ultraviolet radiation
c) Bacterial Lipopolysaccharides
d) Corticosteroids 
15. The following substances are capable of inhibiting the formation of TNF-alpha, except:
a) Pentoxifylline
b) Thalidomide
c) IL-10
d) Tumor cells

16. The following diseases are associated with a Th2 response profile, except:
a) Lepromatous leprosy
b) Graves' disease
c) Atopic Dermatitis
d) Delayed cellular hypersensitivity

17. Which is a Th2 response mediator cytokine, responsible for the humoral response and most manifestations of atopy?
a) IL-8
b) IL-1
c) TNF-alpha
d) IL-4

18. Which is the main TNF-a-producer cell?
a) Macrophage
b) Langerhans Cell
c) B-Lymphocyte
d) Endothelial cells

19. In which region is The TNF-a gene located?
a) The short arm of chromosome 6
b) The short arm of chromosome 9
c) The long arm of chromosome 3
d) The long arm of chromosome 8

20. What is the main function of TNF- $\alpha$ ?

a) Increase hyperproliferative keratin 6

b) Leukocyte recruitment to the site of infection

c) Encourage the immunological synapse "lymphocyteLangerhans cell"

d) Antigen recognition and lysis of intracellular pathogens

\begin{tabular}{|c|c|c|c|}
\hline \multicolumn{4}{|c|}{$\begin{array}{l}\text { Answer key } \\
\text { Pain in photodynamic therapy: mechanism } \\
\text { of action and management strategies } \\
2012 ; 87(4): 521-9 \text {. }\end{array}$} \\
\hline $1-b$ & 6- a & 11-c & $16-d$ \\
\hline $2-a$ & 7- c & $12-\mathrm{c}$ & $17-\mathrm{c}$ \\
\hline $3-b$ & $8-b$ & $13-\mathrm{c}$ & $18-\mathrm{c}$ \\
\hline 4- d & 9- $d$ & 14-c & 19-c \\
\hline 5- c & $10-\mathrm{b}$ & $15-\mathrm{a}$ & $20-\mathrm{b}$ \\
\hline
\end{tabular}

\section{Papers}

Information for all members: The EMCD questionnaire is now available at the homepage of the Brazilian Annals of Dermatology: www.anaisdedermatologia.org.br. The deadline for completing the questionnaire is 30 days from the date of online publication. 